\title{
Announcements
}

The ECONOMIC \& BUSINESS HISTORICAL SOCIETY welcomes proposals for presentations on all aspects of business and economic history at its thirty-first annual conference in Pittsburgh, from April 27 to April 29, 2006. In keeping with its traditions, the Society seeks proposals for both individual papers and panel sessions. Graduate students are invited to apply, and may qualify for reduced registration fees.

Papers presented at the conference may be submitted for publication in the Society's peer-reviewed journal, Essays in Economic and Business History, edited by David Whitten of the University of Auburn University.

Composed of some three hundred North American and international members, the Economic \& Business Historical Society offers participants an opportunity for continuing intellectual interchange within a modest-sized collegial, interdisciplinary group. The Society holds its annual convention in locations of historical significance. Both the annual membership (\$30) and conference registration fees are modest. Final arrangements with the hotel are being concluded and the details will be posted on our Web site in the very near future.

Proposals for individual papers should include an abstract of no more than 500 words, a brief CV, postal and e-mail addresses, and telephone and fax numbers. Panel proposals should also suggest a title and a panel chair. Graduate students and nonacademic affiliates are welcome. Submissions imply that at least one author will register for the conference and be present at the time designated in the conference program. Proposals must be submitted by January 15, 2006.

Proposals may be submitted in one of three ways:

- on line submission using the form on our Web site: http://www. ebhsoc.org/papers.html

- by e-mail to: hsmvn@sunset.backbone.olemiss.edu

- by conventional mail to:

Dr. Michael Namorato

Department of History

The University of Mississippi

University, MS 38677

The HISTORY of ECONOMICS SOCIETY. The thirty-third annual meeting of the History of Economics Society will be held 23-26 June 2006 at Grinnell College in Grinnell, lowa. All persons wishing to present a paper 


\title{
Announcements / 606
}

or organize a complete session should submit an abstract of 200 words or less for a paper or an abstract of 400 words or less for a complete session by February 15, 2006 to President-Elect Bradley Bateman.

For complete sessions, proposals should include names of participants who are expected to attend the meetings. Proposals on all aspects of history of economic thought and methodology are invited.

Proposals may be submitted on-line at:

http://eh.net/HE/HisEcSoc/carchive/HES2006/paperreg.shtml

Proposals may also be sent to:

\author{
Bradley Bateman \\ President-Elect, History of Economics Society \\ Department of Economics \\ Grinnell College \\ Grinnell, IA 50112-1690 \\ e-mail: hes2006@Grinnell.edu \\ Phone: 641-269-3173 \\ Fax: 641-269-4985
}

The EUROPEAN BUSINESS HISTORY ASSOCIATION. The tenth annual conference of the European Business History Association will be held at the Copenhagen Business School on August 17-20, 2006. The conference is organized by the Centre for Business History, Copenhagen, the Centre for Business History, Aarhus, and the Department of History, International and Social Studies, Aalborg. The conference theme will be: "The Dynamics of Capitalism and Business Enterprise: Two Hundred Years of Business Success, Failure, and Scandal." Papers dealing with other issues are also welcomed.

Those interested in presenting a paper should prepare a one-page abstract. Proposals for panels should contain the abstracts of the individual papers as well as a short summary explaining the rationale of putting these together in one panel. Suggestions for chairs and discussants of the panel will also be welcomed. Please e-mail your abstracts or panel proposals by January 15, 2006 to Jørgen Fink at hisjf@hum.au.dk.

The NEWCOMEN DISSERTATION COLLOQUIUM will be held in conjunction with the 2006 annual meeting of the Business History Conference (BHC), June 8-10 in Toronto, Canada, at the Munk Centre for International Studies of the University of Toronto. This intensive workshop, 
sponsored by the BHC through the generous support of the Newcomen Society of the United States, will take place at the conference venue Wednesday evening, June 7 , and Thursday, June 8. Participants will work closely with a small, distinguished group of BHC-affiliated scholars, including at least two of its officers. The assembled scholars and students will review dissertation proposals, consider relevant literatures and research strategies, and discuss the business history profession. Limited to ten students, it is intended for doctoral candidates in the early stages of their dissertation projects. A grant from the Newcomen Society of the United States will provide each participant with a \$300 US honorarium. Those interested in participating should submit to Roger Horowitz, BHC Secretary-Treasurer (rh@udel.edu), a statement of interest, a preliminary or final dissertation prospectus, and a CV. Please make clear that you are interested in the Dissertation Colloquium. One recommendation from the dissertation supervisor (or prospective supervisor) should also be faxed (302-655-3188) or e-mailed to Roger Horowitz by January 15, 2006.

The ECONOMIC HISTORY ASSOCIATION will present the Alice Hanson Jones Prize for an outstanding book in North American (including Caribbean) economic history at its annual meeting in Pittsburgh in September of 2006. This $\$ 1,200$ prize is awarded biennially and alternates with the Gyorgi Ranki Prize for a book in European economic history.

Eligibility and Nominations: Only books published in English during 2004 or 2005 are eligible for the 2006 prize. The author need not be a member of the Association. Authors, publishers, or anyone else may nominate books. In December of 2005 the Association will post procedures for the competition on its Web site and issue an e-mail call for nominations. The announcement will include information on the members of the selection committee and its chair. At that time, authors or publishers will be asked to send a copy of the book, plus a curriculum vitae of the author(s), with current information on addresses and telephone numbers, to each member of the committee. The deadline for submission will be March 1, 2006.

The Economic History Association also announces a new awards program. These awards are open to graduate students who are currently enrolled in a graduate program in a social science discipline, and who are currently engaged in, or considering, dissertation research in economic history. There are no requirements as to discipline or topic area.

Travel grants are available to assist graduate students with travel expenses associated with attendance at the annual meetings of the Eco- 


\section{Announcements / 608}

nomic History Association or the Cliometric Society. Up to twenty such grants may be awarded annually. These awards are intended to help defray costs of transportation and/or lodging, registration, and banquet fees where applicable. A small per diem will also be provided to help cover any other remaining expenses. Application is by faculty nomination. The nominating letter should be sent to each member of the Committee by e-mail. It should describe the student's interest in economic history and (if relevant) dissertation research. It should also include a copy of the student's current $\mathrm{CV}$.

Committee Members

Ben Chabot: remy@umich.edu

Avner Greif: avner@leland.stanford.edu

Price Fishback: pfishback@bpa.arizona.edu

The CLEMENTS CENTER-DEGOLYER LIBRARY Center for Southwest Studies offers research travel grants of $\$ 500$ a week for up to four weeks to applicants living outside the greater Dallas-Fort Worth area to encourage a broader and more intensive use of the special collections at the DeGolyer Library. The library contains over 90,000 volumes of rare and scholarly works, 350,00o photographs, and approximately 40,00o linear feet of archival materials pertaining to the trans-Mississippi West, the Spanish Borderlands, the history of transportation, especially railroads worldwide, and matters of business and labor. Special collections include those of Stanley Marcus and Horton Foote; collections of Texas banknotes and maps; the Women's Archives of the Southwest; petroleum in the West; photography of the West; and the J. C. Penny \& Co. collection. Grant applications are accepted throughout the year.

Web site: www.smu.edu/swcenter

E-mail: swcenter@smu.edu

The AGRICULTURAL HISTORY SOCIETY sponsors several annual awards for various agricultural history publications, manuscripts, and projects. Each year the society announces its award winners at the Agricultural History Society luncheon during the Organization of American Historians conference.

The Gilbert C. Fite Award, which includes a $\$ 300$ honorarium, is given to the author of the best dissertation on any aspect of agricultural 
history, broadly interpreted, completed during the current calendar year in honor of Fite's distinguished corpus of work and lifelong devotion to student excellence.

The Everett E. Edwards Award, with a $\$ 200$ honorarium, is given to the graduate student who submits the best manuscript on any aspect of agricultural and rural studies during the calendar year.

The society offers the Wayne D. Rasmussen Award to the author of the best article on agricultural history published by a journal other than Agricultural History during the calendar year. The award includes an honorarium of $\$ 200$ and certificates for the author and publisher.

The Vernon Carstensen Memorial Award, with an honorarium of $\$ 200$, is presented to the author of the best article published in Agricultural History during the calendar year.

Inquiries should be addressed to:

Claire Strom, Editor

Agricultural History

Minard Hall 203, P.O. Box 5075

North Dakota State University

Fargo, ND 58105

Phone: 701-231-6405

E-mail: Claire.Strom@ndsu.nodak.edu

Web site: ndsu.agricultural.history@ndsu.nodak.edu

JOHN W. HARTMAN CENTER. The John W. Hartman Center for Sales, Advertising, and Marketing History at Duke University in Durham, N.C. offers travel grants up to $\$ 750$ for the use of any of the Hartman Center's collections and will fund up to three J. Walter Thompson Research Fellowships. Each Fellow will receive a stipend of $\$ 1,000$ during his or her stay in Durham. Fellowships are available to researchers planning to spend a minimum of two weeks at Duke doing research that focuses on the J. Walter Thompson Company Archives. The next cycle of awards will be for use between March 2006 and August 2007. Applications must be received or postmarked by January 17, 2006.

For more information about the Hartman Center, please consult our Web site at http://scriptorium.lib.duke.edu/hartman/ or contact Lynn Eaton, Reference Archivist, John W. Hartman Center for Sales, Advertising \& Marketing History, hartman-center@duke.edu, tel. 919-660-5827, fax 919-660-5934. 
The CHEMICAL HERITAGE FOUNDATION. The Chemical Heritage Foundation in Philadelphia, Penn., offers several fellowships and travel grants in the history of science:

The Gordon Cain Fellowship in Technology, Policy, and Entrepreneurship. The Cain Fellowship is open to Ph.D. scholars who plan to conduct historical research on the development of the chemical industries. The outcome of this research should further public understanding of the relationship between technology, policy, management, and entrepreneurship, and shed light on the complex development of modern society and commerce. With Beckman Center staff, the Cain Fellow will organize a conference, inviting scholars to discuss the subject of the fellow's research. Period of fellowship: September 2006May 2007, in residence at CHF. Stipend: $\$ 43,000$; plus small travel allowance. Application deadline: January 15, 2006.

The John C. Haas Fellowship in the History of Chemical Industries. The Haas Fellowship is open to Ph.D. scholars whose projects will enhance public understanding of the role of the chemical industries in relation to environmental, societal, health, and safety issues. Two fellowships are offered. Period of fellowship: September 2006-May 2007, in residence at CHF. Stipend: $\$ 38,000$; travel allowance also available. Application deadline: January 15, 2006.

The Roy G. Neville Fellowship. The Neville Fellowship is open to historians of science, technology, and allied fields, as well as to historians of the book and of print culture, bibliographers, and librarians. Ph.D., Ph.D. candidacy, or equivalent preferred but not required. The fellowship supports two months of intensive work in the Roy G. Neville Chemical Historical Library and includes a stipend of $\$ 6,000$. The fellows will be required to present a lecture at CHF based on their research, and CHF may choose to publish the lecture as an article in Chemical Heritage news magazine, as a short monograph, or as a Web-based publication. Two fellowships offered. Period of fellowship: Summer 2006 (two months in residence at $\mathrm{CHF}$ ). Stipend: $\$ 6,000$; travel allowance also available. Application deadline: February 15, 2006.

The Glenn E. and Barbara Hodsdon Ullyot Scholarship. The Ullyot Scholarship is open to scholars, graduate students, science writers, and journalists who plan to conduct historical research that will advance public understanding of the chemical sciences.

Period of fellowship: Summer 2006 (minimum of two months in residence at CHF). Stipend: $\$ 4,500$; travel allowance also available. Application deadline: February 15, 2006.

Requirements for the above fellowships: Research proposal (not more than 1,000 words) describing the project, the relevance of resources at CHF to the project, how the project will advance historical 
scholarship, and how the outcome might be published; curriculum vitae; and two letters of reference (to be sent directly from the source to CHF).

Submit application materials to:

Fellowship Coordinator

Chemical Heritage Foundation

315 Chestnut Street

Philadelphia, PA 19106-2702

Phone: $215-873-8238$

Fax: 215-925-1954

E-mail: fellowships@chemheritage.org

CHF also offers travel grants for research at its Othmer Library of Chemical History. Applicants are also encouraged to use other CHF resources, including its archival collections and oral histories, as well as explore Philadelphia area resources. These grants may be used for travel, food, lodging, and copying costs. For researchers within the United States, grants are in the range of $\$ 500$. Individuals traveling internationally may be considered for grants in the range of $\$ 1,000$. Application deadline: Ongoing.

Requirements: One-page statement of the research project and the applicability of CHF's resources; curriculum vitae; budget estimate; and one letter of reference (to be sent directly from the source to $\mathrm{CHF}$ ).

Submit application materials to:

CHF Travel Grants

Chemical Heritage Foundation

315 Chestnut Street

Philadelphia, PA 19106-2702

Phone: 215-925-2222

Fax: 215-925-1954

E-mail: travelgrants@chemheritage.org 